\title{
Status of Higher Education for Women in Odisha: an Inter District Analysis
}

\author{
Sadhana Satapathy*
}

\begin{abstract}
Higher Education (H.E) in general, unlike basic education and health, is not a matter of right. Neither it is of immense importance for the policy makers as there are already too many problems to handle. This is more so in the case of a big and poor country like India. The same logic applies to Odisha where the priorities are in favour of basic needs. However, the role of higher education as nurturing the thinking and opinion making class on behalf of the society cannot be undermined. What about higher education for Women? It is well known that education in general and women's education in particular is a reflection of a nation's state of development. However, progress in literacy and reduction of high dropout rate may not be accepted as the only solution for further development. In this context, it is pertinent to study women's higher education. There are a lot of studies on India as a whole. Odisha, one of the backward states in almost all parameters, lags behind the rest of the states in women's education also. However, state figures cannot give a clear picture regarding the inter-district disparity. The present paper attempts to look at the problem of women's higher education from district perspectives. It finds that higher education for women is a visibly neglected area of research. 2011 census data reveals that only $6.67 \%$ of literates of the state are graduates or above which is less than national average of $8.15 \% .12 .03 \%$ have studied till matriculation and $6.5 \%$ population has shown higher secondary as the highest qualification.65.93\% of graduates are non technical. The present study using 2011 Census data for education finds that a high percentage of graduates and above women goes for graduation without technology. There is huge inter district disparities across social groups in Higher Education completed by women. Thus too much emphasis on literacy and providing incentives for literacy programmes only overshadows the importance of higher education for women which is significant in the long run. The policies should be such that more and more women opt for higher education. Proper planning and implementation of schemes would go a long way to help these districts.
\end{abstract}

Key Words: Higher education, SC \&ST Women, 2011 Census*Reader in Economics, B.J.B(Auto) College, Bhubaneswar.

\section{INTRODUCTION}

The importance of education in promoting economic development is a well-known fact. Though the emphasis of policy makers is mostly on primary education, the importance of higher education cannot be ignored. Higher education (henceforward HE) in India starts after senior secondary education comprising of three stages i.e. (a) graduate (b) postgraduate (c) research/doctorate degree. Vocational/technical/professional education starts at the school level and is followed by course up to graduation, post graduation and research in that order.

Unlike primary education, health care or similar basic needs, HE in general is not a matter of right. This is more so in the case of a big and poor country like India. The same logic applies to Orissa where the priorities are in favour of basic needs. However, HE's role as nurturing the task of thinking and opinion making class on behalf of the society cannot be undermined. It is another matter whether HE is really producing qualitative people or merely producing more quantity of educated youth who do not find appropriate employment which has to be looked into separately.

There are certain characteristics of Higher Education (HE) which are unique to it. By its very nature, it is a selective field. It is not an universalisable human resource. On the other hand, the kind of social prestige and upward mobility which is associated with HE based professions, there will always be an increasing number of aspirants. More will want to get in than that can be accommodated. It is one of the most important avenues of mobility of all classes including the affluent class in every society in general and in a big and developing country like India in particular. Given the resource crunch, it is obvious that expenditure on HE, particularly public expenditure, is very little. HE is almost entirely state funded in our country. Financing by government is a major instrument for its development. Government of India has classified education beyond elementary level i.e. secondary and HE as non-merit goods or merit-2 goods. These are at the lowest rung of receiving public subsidies. State governments are responsible for providing establishments of state universities and colleges. State provides plan grants for development and non-plan grants for maintenance of HE institutions. 
Expenditure on HE as a percentage of GDP has remained stagnant in India and is very less compared to that of U.S, U.K and China which are $1.41 \%, 1.07 \%$ and $0.51 \%$ respectively. It is only since 1997-98 that there has occurred an increase in the share of public expenditure on HE. On the other hand total student enrolment in higher educational institutions in India has been increasing rapidly over the past half century from 2, 00,000 in 1950 's to almost seven million by the end of 2000. The steep decline in the share of expenditure has more to do with resource scarcity experienced by the government rather than a belief that higher education is not important. Higher education for women in India is somehow relegated to the backside by emphasizing too much on female literacy. However the effective participation of women is very vital at all levels of development. Educating women is not a charity. It is a good economics and if developing nations are to abolish poverty, they should educate their women. The landmark in the history of women's higher education was laid when the first woman was admitted at the University of Calcutta in 1877.

The level of Women's Education in India witnessed a sharp rise between 2001 and 2011. 116\% more women pass out as graduates or above compared to $65 \%$ increase among men. There is a $151 \%$ rise in women completing post graduation and $196 \%$ rise in women earning professional and technical degrees. More than 68 million people are graduates or more qualified in 2011.This is over 85 of 838 million people who were 15 years age or older. In 2001 it was about $7 \% .12$ million are at present with technical degrees compared to about 5 million in 2001 .In terms of percents, this is only $1.4 \%$ of the total $15+$ years population in India.

\begin{tabular}{|c|c|c|c|}
\hline \multicolumn{4}{|c|}{$\begin{array}{l}\text { Table 1: A Comparative Figure of percentage increase in Higher } \\
\text { Education of Men and Women 2001-2011 }\end{array}$} \\
\hline Women & Men & Women & Men \\
\hline \multicolumn{2}{|c|}{ Total $15+$ years Population } & \multicolumn{2}{|c|}{ medicine } \\
\hline 27 & 25 & 157 & 74 \\
\hline \multicolumn{2}{|c|}{ Graduate and above } & \multicolumn{2}{|c|}{ Ag \& Dairy } \\
\hline 116 & 65 & 102 & 59 \\
\hline \multicolumn{2}{|c|}{ Graduate(non- technical) } & \multicolumn{2}{|c|}{ Veterinary } \\
\hline 91 & 48 & 154 & 56 \\
\hline \multicolumn{2}{|c|}{ Post Graduate( Non-Technical) } & \multicolumn{2}{|c|}{ Teaching } \\
\hline 151 & 87 & 122 & 80 \\
\hline \multicolumn{2}{|c|}{ Engineering } & & \\
\hline 326 & 150 & & \\
\hline
\end{tabular}

Source: Census 2011, 2001

In this context one is tempted to see the status of women's HE in Odisha across social groups and different districts. The present paper tries to analyse the status of HE for women.

Objectives and Methodology: The objectives of the paper are

1. To analyse the status of women's higher education in Odisha.

2. To have a spatial- both inter district and rural urban- analysis of higher education for women in Odisha.

3. To analyse the higher education status of SC and ST women of Odisha..

2011 census data has been used for the spatial analysis of women's higher education across classes. The methodology used is simple tabular forms and statistical tools such as percentages and ratios. The comparison between two census data(2001 \& 2011) has been dropped deliberately since it is felt that even at present the situation of education for women in general and HE for women in particular has not drastically improved for Odisha vis a vis other states though it might have in any case increased. The concern here is higher education instead of literacy

\section{II}

\section{WOMEN'S HIGHER EDUCATION IN ODISHA: THE PAST AND THE EMERGING ISSUES}

In the state, the establishment of the First Girls High School by Commissioner of Cuttack, $\mathrm{Mr}$ Ravenshaw in 1906 and the efforts of Reba Roy and Rani of Khallikote in spreading female education in the beginning of the 20th century indicate the emerging social awareness on the need for education among women. Female literacy in Odisha has been lower than male literacy and has consistently been below the Indian level. 
The gender gap also remains at a high 18\% (Male-82.40 and female - 64.36, 2011 Census) -an indication of gender bias. As per the 2011 Census, the overall literacy stood at 73.45 .

Prior to the beginning of twentieth century, the condition of higher education for women in Odisha was deplorably poor. On 14th June 1914, the 'Female Education Committee' was appointed to examine the position of higher education for women, in Bihar and Odisha. As there was not a single institution of higher education for women in Odisha, the committee suggested for the opening of intermediate classes for women in Revenshaw Girls' school, Cuttack. According to the suggestion of the academic session 1915-16, intermediate classes were started in Ravenshaw Girls' School, only with 8 students on the roll. But due to financial constraints, the intermediate classes were closed by the year 1917. Over the time, the intermediate college was revived in 1925 and placed on a permanent footing, as it was the only of its kind in Odisha. At the beginning it was affiliated to Patna University. The affiliation was transferred to Utkal University in 1943. Till independence it was the only institution for women in the state. At the advent of Independence, sixty four lady students were studying in that institution. By that time, 104 lady students were studying in co-ed institutions. As there was no degree college for women in the state, most of the women students desirous of studying degree course were compelled to study in boys colleges. A negligible number of lady students were also studying in Medical and teacher training colleges. However, for making the university education more relevant for girls, subsequently Domestic Science was introduced in the I.A classes. Degree classes were introduced in Women's college stationed at Ravenshaw Girls' school in 1946-47 which was later renamed as Sailabala Women's College. The number of women students gradually increased from 84 to 93 by 1948 . By that time 126 women students were studying in mixed colleges, including 19 in the Medical College and 4 in the Cuttack Training College. By the year 1957-58, the women enrolment in colleges increased to 730 and to 781 by the year 1966-67. Higher education was mainly confined to the upper and middle class strata in the urban areas.

The number of women's colleges increased from 10 in 1977 to 40 in 1986. The enrolment increased from 14112 to 48334 for the same period. However, the establishment of Women's Colleges in each district head quarters had gone a long way in removing the disparities in access to higher education between the educationally advanced and backward districts of the state. By the year 2000 there were altogether 1367 colleges in the state including 175 Women's Colleges. But in all the colleges women students were getting the opportunity to study. During the post-independence period Radhakrishnan Commission (1948) was formed, which influenced the development of higher education. Before that in the year 1943, Utkal University was established, and higher education started expanding. As a result of the impact of Radhakrishnan Commission, there was a growing demand for higher education in the state. The number of colleges increased to 14 including one women's college with an enrolment of 6,671 at the beginning of the First Plan period (1951-52). Setting up one University prior to independence was no doubt a great achievement. The number of colleges increased to 36 with an enrolment of 12,977 boys and 1,792 girls during $1^{\text {st }}$ and $2^{\text {nd }}$ Plans. With the recommendation of the Kothari Commission (1964-66), three more women's colleges were' opened, during the Third Plan. Thus the tolal number of women's colleges rose to 7. The main objective of the Fourth Plan was the larger participation of the girl students in colleges. The number of women's colleges was 8 with an enrolment of 8910 women students by the end of Fourth Five Year Plan. The percentage of enrolment of women students to total population in the age group of (17-22) was only 0.4 percent during the First Plan, while it was only 2 percent by the end of the Fourth Plan. This is the general overview of higher education for women in the state.

By the end of the 1989-90, the total number of colleges for general education was 459, out of which, 50 were women's colleges. The total number of enrolment during this time was 263,208 out of which 61,196 were girls. This figure shows a wide disparity between boys and girls enrolment rate at higher education level. The recent formation of Ramadevi Women's University heading thirty six women's colleges in the state in 2015-16is the reflection of importance given to women's higher education in the state.

\section{III}

\section{Higher Education and Women in Odisha: Inter District Disparities}

2011 census data reveals that only $6.67 \%$ of literates of the state of Odisha are graduates or above which is less than national average of $8.15 \% .12 .03 \%$ have studied till matriculation and $6.5 \%$ population has shown higher secondary as the highest qualification; $65.93 \%$ of graduates are non technical ; $16.49 \%$ are P.Gs; $11.6 \%$ are engineers and tech degree holders; $1.6 \%$ have medicine degrees. Among medicine graduates SCs constitute $3.9 \%$ and STs constitute $2.81 \%$. Similarly among engineers, it is $7 \%$ and $4.5 \%$ for SC and ST respectively. 
In the above context what is the percentage of women having got higher education vis-à-vis the literate women? As already mentioned the importance of HE can never be undermined neither the HE of women vis-àvis that of men is going to be drastically changing. Table 2 below shows the percentage of females, literate females as a percentage of total literate population and percentage of female literates of different districts across rural and urban classifications. It is observed that they are quite comparable with one another.

\begin{tabular}{|c|c|c|c|c|c|c|c|c|c|c|}
\hline \multicolumn{11}{|c|}{$\begin{array}{l}\text { TABLE 2: FEMALE POPULATION(\%), FEMALE LITERACY (as a \% of literate population) } \\
\text { and FEMALE LITERATES AS a \% OF FEMALE POPULATION(RURAL\&URBAN) }\end{array}$} \\
\hline & & \multicolumn{3}{|c|}{$\%$ of total population } & \multicolumn{3}{|c|}{$\begin{array}{l}\% \text { of literate } \\
\text { population }\end{array}$} & \multicolumn{3}{|c|}{$\begin{array}{l}\text { literate as a } \% \text { of total } \\
\text { females }\end{array}$} \\
\hline & & Total & Rural & Urban & Total & Rural & Urban & Total & Rural & Urban \\
\hline $\begin{array}{c}\text { Sl } \\
\text { No }\end{array}$ & & 1 & 2 & 3 & 4 & 5 & 6 & 7 & 8 & 9 \\
\hline 1 & Bargarh & 49.42 & 49.47 & 49.00 & 43.36 & 43.05 & 45.70 & 58.27 & 56.82 & 71.22 \\
\hline 2 & Jharsuguda & 48.80 & 49.43 & 47.86 & 43.80 & 43.63 & 44.04 & 62.86 & 59.54 & 68.04 \\
\hline 3 & Sambalpur & 49.39 & 49.70 & 48.66 & 44.12 & 43.46 & 45.46 & 60.38 & 56.18 & 70.60 \\
\hline 4 & Debagarh & 49.37 & 49.45 & 48.35 & 43.05 & 42.89 & 44.83 & 55.20 & 54.20 & 68.41 \\
\hline 5 & Sundargarh & 49.31 & 49.98 & 47.83 & 44.12 & 42.40 & 44.90 & 57.37 & 48.24 & 71.25 \\
\hline 6 & Kendujhar & 49.69 & 50.12 & 47.91 & 42.51 & 43.55 & 43.08 & 49.97 & 50.15 & 61.06 \\
\hline 7 & Mayurbhanj & 50.15 & 50.25 & 48.87 & 42.01 & 41.50 & 46.12 & 45.53 & 43.32 & 72.90 \\
\hline 8 & Baleshwar & 48.90 & 48.89 & 48.94 & 44.34 & 44.08 & 46.32 & 63.35 & 62.37 & 71.32 \\
\hline 9 & Bhadrak & 49.53 & 49.62 & 48.88 & 45.50 & 45.51 & 45.49 & 66.73 & 67.00 & 64.82 \\
\hline 10 & Kendrapara & 50.16 & 50.25 & 48.81 & 46.76 & 46.77 & \begin{tabular}{|l|}
46.47 \\
\end{tabular} & 70.49 & 70.22 & 74.97 \\
\hline 11 & Jagatsinghapur & 49.18 & 49.38 & 47.36 & 45.89 & 46.01 & 44.85 & 72.97 & 72.84 & 74.16 \\
\hline 12 & Cuttack & 48.46 & 48.59 & 48.12 & 45.16 & 44.60 & 46.48 & 71.43 & 68.44 & 79.19 \\
\hline 13 & Jajapur & 49.32 & 49.38 & 48.56 & 45.26 & 45.21 & 45.83 & 64.81 & 64.31 & 71.23 \\
\hline 14 & Dhenkanal & 48.64 & 48.73 & 47.86 & 44.08 & 43.88 & 45.62 & 63.05 & 61.60 & 76.57 \\
\hline 15 & Anugul & 48.52 & 48.81 & 47.07 & 43.13 & 42.92 & 44.10 & 60.67 & 58.42 & 72.76 \\
\hline 16 & Nayagarh & 47.79 & 47.79 & 47.81 & 43.00 & 42.80 & 45.02 & 64.33 & 63.42 & 74.42 \\
\hline 17 & Khordha & 48.17 & 48.96 & 47.31 & 45.28 & 45.13 & 45.43 & 73.07 & 67.88 & 78.84 \\
\hline 18 & Puri & 49.06 & 49.21 & 48.23 & 45.44 & 45.31 & 46.12 & 70.45 & 69.50 & 75.71 \\
\hline 19 & Ganjam & 49.58 & 49.89 & 48.49 & 42.87 & 42.16 & \begin{tabular}{|l|}
44.87 \\
\end{tabular} & 54.14 & 50.05 & 69.27 \\
\hline 20 & Gajapati & 51.04 & 51.17 & 50.15 & 41.47 & 40.45 & 45.87 & 36.91 & 33.23 & 63.91 \\
\hline 21 & Kandhamal & 50.90 & 51.04 & 49.61 & 41.49 & 40.74 & 46.14 & 44.45 & 41.53 & 71.92 \\
\hline 22 & Baudh & 48.63 & 49.82 & 48.63 & 44.74 & 41.39 & 44.74 & 71.61 & 50.50 & 71.61 \\
\hline 23 & Subarnapur & 48.98 & 49.02 & 48.58 & 42.17 & 42.00 & 43.86 & 56.22 & 55.29 & 66.75 \\
\hline 24 & Balangir & 49.66 & 49.80 & 48.66 & 41.15 & 40.45 & 44.89 & 46.60 & 43.68 & 68.52 \\
\hline 25 & Nuapada & 50.53 & 50.59 & 49.58 & 39.57 & 39.12 & 44.87 & 38.42 & 37.02 & 62.50 \\
\hline 26 & Kalahandi & 50.08 & 50.19 & 48.80 & 39.63 & 39.01 & 44.66 & 40.25 & 38.13 & 66.23 \\
\hline 27 & Rayagada & 51.24 & 51.55 & 49.52 & 40.66 & 39.29 & 44.76 & 33.43 & 28.39 & 62.72 \\
\hline 28 & Nabarangapur & 50.46 & 50.52 & 49.74 & 38.99 & 38.08 & 45.25 & 29.77 & 27.30 & 62.14 \\
\hline 29 & Koraput & 50.80 & 51.12 & 49.14 & 40.00 & 37.95 & 45.06 & 32.43 & 26.03 & 66.36 \\
\hline 30 & Malkangiri & 50.48 & 50.70 & 48.06 & 39.93 & 39.65 & 41.78 & 31.56 & 29.54 & 55.86 \\
\hline & ODISHA & 49.46 & 49.71 & 48.23 & 43.57 & 43.14 & 45.29 & 56.13 & 53.06 & 71.93 \\
\hline
\end{tabular}

Only Nuapada, Kalahandi and Malkangiri (all KBK districts) have $<40 \%$ female literacy. However, if one looks at the female literacy as the percentage of respective female population (columns 7,8 and 9) one finds a huge disparity and more districts are included. Nabarangpur is having least percentage of female population literate in total and rural figures. The focus here is to look at the disparity among the females across different districts. 
Table 3 and 4 analyse the status of female literates as a percentage of female population for SC and ST categories of the state. The position of SC female population is comparatively better than that of STs. The coloured districts are showing the least percentages, within the subgroup of SC and ST.

\begin{tabular}{|c|c|c|c|c|c|c|c|c|c|c|}
\hline \multicolumn{11}{|c|}{$\begin{array}{l}\text { TABLE 3: SC FEMALE POPULAION(\%), SC FEMALE LITERACY( as a \% of literate SC population) and } \\
\text { FEMALE LITERATES AS A \% OF FEMALE SC POPULATION(RURAL/URBAN) }\end{array}$} \\
\hline & & \multicolumn{3}{|c|}{$\begin{array}{l}\% \text { of Female } \\
\text { population(SC) }\end{array}$} & \multicolumn{3}{|c|}{$\begin{array}{l}\text { Female literates as a } \\
\% \text { of literate } \\
\text { population }(\mathrm{SC})\end{array}$} & \multicolumn{3}{|c|}{$\begin{array}{l}\text { Female literates as a } \\
\% \text { of total females(SC) }\end{array}$} \\
\hline & & 1 & 2 & 3 & 4 & 5 & 6 & 7 & 8 & 9 \\
\hline $\begin{array}{l}\text { Sl } \\
\text { No }\end{array}$ & Districts & Total & Rural & Urban & Total & Rural & Urban & Total & Rural & Urban \\
\hline 1 & Bargarh & 49.66 & 49.64 & 49.77 & 42.32 & 42.07 & 44.39 & 50.96 & 50.20 & 57.90 \\
\hline 2 & Jharsuguda & 49.74 & 49.96 & 49.32 & 43.64 & 43.56 & 43.79 & 57.68 & & \\
\hline 3 & Sambalpur & 49.69 & 49.61 & & & 42.53 & & & & \\
\hline 4 & Debag & 49.45 & & & & & & & & \\
\hline 5 & Sundargarh & 49.67 & 50.14 & 48.95 & 43.61 & 43.38 & 91 & 51 & 70 & 41 \\
\hline 6 & Kend & 50.00 & 50.10 & 49.51 & 43.30 & 43.48 & 42.43 & 55.56 & 97 & 60 \\
\hline 7 & Mayurbhan & 50.12 & 50.12 & 50.09 & 42.61 & 42.23 & 45.04 & 49.08 & 47.56 & \\
\hline 8 & Balesh & 49.10 & 49.09 & 49.24 & 42.66 & 42.52 & 44.58 & 54.47 & 53.99 & 1.47 \\
\hline 9 & Bhadrak & 49.63 & 49.63 & 49.63 & 42.96 & 42.92 & 43.68 & 55.25 & 55.16 & 56.80 \\
\hline 10 & Kendrapara & 49.79 & 49.83 & 49.17 & 43.91 & 43.95 & 43.23 & 57.78 & 57.69 & 59.49 \\
\hline 11 & Jagatsir & 49.55 & 49.66 & 48.07 & 44.31 & 44.34 & 43.87 & 62.74 & 62.44 & 67.07 \\
\hline 12 & Cuttack & 48.97 & 48.94 & 49.08 & 43.11 & 42.64 & 45.04 & 59.30 & 57.81 & 65.89 \\
\hline 13 & Jajapur & 49.11 & 49.11 & 49.07 & 42.73 & 42.69 & 43.60 & 53.34 & 53.09 & 59.30 \\
\hline 14 & Dhenkanal & 49.27 & 49.30 & 48.94 & 42.79 & 42.67 & 43.99 & 53.86 & 53.14 & 62.03 \\
\hline 15 & Anugul & 49.30 & 49.39 & 48.75 & 42.43 & 42.25 & 43.36 & 52.25 & 50.94 & 60.14 \\
\hline 16 & Nayagarh & 48.82 & 48.79 & 49.11 & 41.85 & 41.71 & 43.32 & 53.46 & 52.89 & 60.21 \\
\hline 17 & Khordha & 49.06 & 49.44 & 48.41 & 43.72 & 43.63 & 43.87 & 60.12 & 57.62 & 64.59 \\
\hline 18 & Puri & 49.45 & 49.47 & 49.22 & 43.65 & 43.60 & 44.18 & 58.99 & 58.82 & 60.80 \\
\hline 19 & Ganja & 50.29 & 50. & 49.85 & 40.05 & 39.62 & 41 & 40.99 & 35 & \\
\hline 20 & Gajap & & & & & & & & & \\
\hline 21 & Kan & & & & & & & & & \\
\hline 22 & $\mathrm{~B}$ & 49 & & 48 & & & & & & \\
\hline 23 & Subarnapur & 48. & 48.93 & 49.36 & 41.29 & 41.20 & 42.20 & 51.18 & 50.79 & 55.56 \\
\hline 24 & Balangir & 49.67 & 49.70 & 49.40 & 41.25 & 40.89 & 43.64 & 45.43 & 43.81 & 59.03 \\
\hline 25 & Nuapada & 50.41 & 50.34 & 51.17 & 40.48 & 40.08 & 44.22 & 41.23 & 40.30 & 51.32 \\
\hline 26 & Kalahandi & 50.40 & 50.38 & 50.67 & 41.10 & 40.72 & 44.72 & 43.33 & 42.08 & 58.55 \\
\hline 27 & Rayagada & 51.21 & 51.23 & 51.09 & 39.85 & 39.23 & 42.31 & 35.15 & 33.01 & 46.07 \\
\hline 28 & Nabarangapur & 50.25 & 50.14 & 51.11 & 41.54 & 41.05 & 44.71 & 40.24 & 38.77 & 51.77 \\
\hline 29 & Koraput & 50.75 & 50.82 & 50.47 & 39.80 & 38.71 & 43.09 & 34.44 & 30.74 & 51.12 \\
\hline 30 & Malkangiri & 49.35 & 49.31 & 49.66 & 41.55 & 41.57 & 41.37 & 46.16 & 46.10 & 46.67 \\
\hline & ODISHA & 49.67 & 49.70 & 49.47 & 42.41 & 42.19 & 43.67 & 51.12 & 50.02 & 58.18 \\
\hline
\end{tabular}

\begin{tabular}{|c|c|c|c|c|c|c|c|c|c|c|}
\hline \multicolumn{11}{|c|}{$\begin{array}{l}\text { TABLE 4: ST FEMALE POPULAION(\%), ST FEMALE LITERACY( as a \% of literate ST } \\
\text { population) and FEMALE LITERATES AS A \% OF FEMALE ST POPULATION(RURAL/URBAN) }\end{array}$} \\
\hline & & $\begin{array}{l}\% \text { of } F \\
\text { popula }\end{array}$ & & & $\begin{array}{l}\text { Fem } \\
\text { of li }\end{array}$ & -1 & $\begin{array}{l}\text { a } \% \\
\text { on }\end{array}$ & & & \\
\hline $\mathrm{Sl}$ & $\mathrm{Di}$ & Tota & Rura & Urban & Tot & Rurc & Urba & Total & Rural & Urb \\
\hline
\end{tabular}


Status of Higher Education of Women in Odisha: An Inter District Analysis

\begin{tabular}{|c|c|c|c|c|c|c|c|c|c|c|}
\hline No & & & & & & & & & & \\
\hline 1 & Bargarh & 50.01 & 49.97 & 51.12 & 41.94 & 41.75 & 46.33 & 47.99 & 47.53 & 59.97 \\
\hline 2 & Jharsuguda & 50.06 & 50.08 & 50.00 & 42.81 & 42.72 & 43.16 & 52.18 & 51.64 & 54.24 \\
\hline 3 & Sambalpur & 50.02 & 50.09 & 49.42 & 42.41 & 42.36 & 42.85 & 48.94 & 48.49 & 52.91 \\
\hline 4 & Debagarh & 50.07 & 50.15 & 48.53 & 41.57 & 41.50 & 42.78 & 44.13 & 43.72 & 52.46 \\
\hline 5 & Sundargarh & 50.41 & 50.44 & 50.23 & 43.83 & 43.39 & 45.92 & 48.87 & 46.77 & 61.29 \\
\hline 6 & Kendujhar & 50.43 & 50.49 & 49.66 & 39.50 & 39.51 & 39.41 & 34.51 & 34.30 & 37.36 \\
\hline 7 & Mayurbhanj & 50.63 & 50.63 & 50.48 & 39.62 & 39.38 & 45.59 & 34.94 & 34.34 & 56.31 \\
\hline 8 & Baleshwar & 50.03 & 50.07 & 49.58 & 38.78 & 38.55 & 41.41 & 32.06 & 31.66 & 37.14 \\
\hline 9 & Bhadrak & 49.52 & 49.34 & 50.24 & 38.29 & 37.78 & 40.25 & 27.19 & 26.63 & 29.39 \\
\hline 10 & Kendrapara & 49.94 & 50.08 & 47.91 & 43.11 & 43.20 & 41.52 & 44.64 & 45.04 & 38.59 \\
\hline 11 & Jagatsinghapur & 46.25 & 45.87 & 46.76 & 38.58 & 37.60 & 39.77 & 46.20 & 43.57 & 49.71 \\
\hline 12 & Cuttack & 49.40 & 49.51 & 48.64 & 40.04 & 39.41 & 43.30 & 39.58 & 37.40 & 54.60 \\
\hline 13 & Jajapur & 49.78 & 49.73 & 50.32 & 37.21 & 36.83 & 40.86 & 29.08 & 28.40 & 36.79 \\
\hline 14 & Dhenkanal & 50.09 & 50.08 & 50.34 & 41.58 & 41.49 & 44.03 & 42.29 & 42.07 & 48.65 \\
\hline 15 & Anugul & 49.90 & 50.02 & 48.78 & 41.41 & 41.44 & 41.14 & 43.13 & 42.65 & 47.71 \\
\hline 16 & Nayagarh & 50.29 & 50.41 & 44.66 & 41.28 & 41.25 & 42.29 & 47.57 & 47.29 & 63.51 \\
\hline 17 & Khordha & 48.64 & 50.12 & 46.51 & 41.06 & 40.00 & 42.13 & 50.78 & 41.08 & 65.78 \\
\hline 18 & Puri & 47.14 & 48.60 & 43.49 & 39.90 & 39.41 & 40.76 & 54.83 & 46.76 & 77.40 \\
\hline 19 & Ganjam & 50.25 & 50.42 & 47.33 & 39.46 & 38.97 & 43.97 & 33.14 & 31.13 & 69.61 \\
\hline 20 & Gajapati & 51.58 & 51.60 & 50.59 & 39.11 & 38.82 & 47.89 & 27.35 & 26.70 & 70.19 \\
\hline 21 & Kandhamal & 51.50 & 51.46 & 52.82 & 40.57 & 40.13 & 49.42 & 38.56 & 37.56 & 68.98 \\
\hline 22 & Baudh & 50.58 & 50.62 & 45.67 & 39.81 & 39.77 & 43.46 & 42.66 & 42.42 & 73.13 \\
\hline 23 & Subarnapur & 49.65 & 49.70 & 48.40 & 41.74 & 41.76 & 41.01 & 48.93 & 48.91 & 49.63 \\
\hline 24 & Balangir & 50.31 & 50.34 & 49.77 & 38.92 & 38.69 & 43.55 & 36.56 & 35.93 & 53.68 \\
\hline 25 & Nuapada & 51.31 & 51.32 & 50.23 & 38.10 & 38.07 & 40.50 & 32.13 & 32.03 & 40.97 \\
\hline 26 & Kalahandi & 50.79 & 50.80 & 50.60 & 37.10 & 36.88 & 44.62 & 30.50 & 30.04 & 53.79 \\
\hline 27 & Rayagada & 52.20 & 52.23 & 51.36 & 38.47 & 38.28 & 41.75 & 22.47 & 21.93 & 37.04 \\
\hline 28 & Nabarangapur & 50.82 & 50.80 & 51.70 & 37.04 & 36.82 & 44.14 & 22.95 & 22.58 & 41.06 \\
\hline 29 & Koraput & 51.64 & 51.69 & 50.54 & 37.33 & 36.97 & 41.19 & 20.97 & 19.95 & 40.92 \\
\hline \multirow[t]{2}{*}{30} & Malkangiri & 51.58 & 51.61 & 50.02 & 38.66 & 38.58 & 40.59 & 21.34 & 20.93 & 39.16 \\
\hline & ODISHA & 50.71 & 50.77 & 49.78 & 40.17 & 39.84 & 43.69 & 34.82 & 33.66 & 52.67 \\
\hline
\end{tabular}

Thus we find that as far as female literacy is concerned, except a few districts, the figures are almost similar. In other words, the degree of inter district variation seems to be less. However, the picture is different for higher education across the different districts of Odisha. Before going for analysis it should be appropriate to discuss a little about the definition of higher education. We have relied on Census data for this. The census data defines higher education as graduates and above. It is composed of graduates other than technical degrees, post graduate other than technical degrees, engineering and technology, medicine, agriculture and dairying, veterinary, teaching and others. The data is for $15+$ years and the respective total population is $15+$ literate populations. Since the aim of the present study is to see what happens to HE for women within the group of female literates, we have considered the data relating to $15+$ female literate population only.

Table 5 below shows that $4.10 \%$ of total literate females have qualifications of graduates and above. Among the SC and ST female literates, only $1.31 \%$ of SC literate females and $0.62 \%$ of ST literate female have qualifications of graduates and above. The urban ST females are doing better than the urban SC females. Regarding the performance of districts we find the KBK districts are way behind.The district wise figures shows the sorry state of HE status in Odisha. 


\begin{tabular}{|c|c|c|c|c|c|c|c|c|c|c|}
\hline & Districts & & S.C & & & ST & & & All Grou & \\
\hline & & Rural & Urban & Total & Rural & Urban & Total & Rural & Urban & Total \\
\hline 1 & Bargarh & 0.64 & 2.25 & 0.79 & 0.34 & 3.63 & 0.46 & 1.59 & 10.03 & 2.44 \\
\hline 2 & Jharsuguda & 1.06 & 2.39 & 1.51 & 0.48 & 2.48 & 0.90 & 1.99 & 8.68 & 4.58 \\
\hline 3 & Sambalpur & 1.06 & 2.88 & 1.55 & 0.57 & 3.43 & 0.87 & 1.97 & 12.55 & 5.12 \\
\hline 4 & Sambalpur & 0.69 & 3.54 & 0.90 & 0.53 & 2.85 & 0.64 & 1.82 & 11.66 & 2.53 \\
\hline 5 & Sundargarh & 1.39 & 4.69 & 2.69 & 1.04 & 5.79 & 1.76 & 1.78 & 12.48 & 5.61 \\
\hline 6 & Kendujhar & 1.55 & 3.40 & 1.87 & 0.44 & 1.89 & 0.54 & 2.19 & 10.02 & 3.27 \\
\hline 7 & Mayurbhanj & 1.42 & 5.22 & 1.88 & 0.57 & 4.41 & 0.68 & 1.68 & 13.30 & 2.63 \\
\hline 8 & Baleshwar & 1.39 & 4.02 & 1.57 & 0.39 & 1.61 & 0.48 & 3.66 & 13.26 & 4.76 \\
\hline 9 & Bhadrak & 1.08 & 3.84 & 1.24 & 0.38 & 0.83 & 0.47 & 3.57 & 9.81 & 4.32 \\
\hline 10 & Kendrapara & 1.28 & 2.84 & 1.36 & 0.60 & 2.94 & 0.78 & 4.01 & 9.40 & 4.31 \\
\hline 11 & Jagatsinghapur & 1.68 & 4.22 & 1.84 & 2.54 & 4.18 & 3.28 & 4.51 & 9.85 & 5.02 \\
\hline 12 & Cuttack & 1.44 & 4.74 & 2.06 & 0.29 & 4.76 & 0.89 & 4.10 & 17.43 & 7.91 \\
\hline 13 & Jajapur & 0.91 & 2.70 & 0.98 & 0.25 & 1.63 & 0.36 & 3.73 & 11.42 & 4.28 \\
\hline 14 & Dhenkanal & 0.68 & 3.79 & 0.94 & 0.26 & 1.92 & 0.31 & 2.39 & 13.49 & 3.51 \\
\hline 15 & Anugul & 0.81 & 3.22 & 1.17 & 0.34 & 3.10 & 0.62 & 2.49 & 12.47 & 4.12 \\
\hline 16 & Nayagarh & 0.62 & 2.89 & 0.80 & 0.18 & 3.38 & 0.23 & 1.97 & 9.56 & 2.62 \\
\hline 17 & Khordha & 1.52 & 6.42 & 3.29 & 0.42 & 8.19 & 3.32 & 3.85 & 21.95 & 12.59 \\
\hline 18 & Puri & 1.23 & 2.84 & 1.37 & 1.02 & 8.24 & 2.58 & 3.55 & 12.28 & 4.92 \\
\hline 19 & Ganjam & 0.28 & 1.98 & 0.59 & 0.15 & 8.46 & 0.63 & 0.93 & 9.22 & 2.80 \\
\hline 20 & Gajapati & 0.49 & 2.33 & 0.96 & 0.20 & 4.53 & 0.25 & 0.59 & 7.68 & 1.54 \\
\hline 21 & Kandham & 0.72 & 3.75 & 1.12 & 0.42 & 5.60 & 0.58 & 0.81 & 9.10 & 1.67 \\
\hline 22 & Baudh & 0.35 & 3.11 & 0.50 & 0.16 & 5.03 & 0.21 & 0.85 & 9.43 & 1.28 \\
\hline 23 & Subarnapur & 0.41 & 1.99 & 0.54 & 0.29 & 3.34 & 0.39 & 1.22 & 6.85 & 1.69 \\
\hline 24 & Balangir & 0.65 & 4.14 & 1.04 & 0.19 & 3.26 & 0.30 & 0.84 & 11.43 & 2.16 \\
\hline 25 & Nuapada & 0.52 & 2.39 & 0.68 & 0.13 & 1.20 & 0.14 & 0.83 & 8.33 & 1.27 \\
\hline 26 & Kalahandi & 0.59 & 3.48 & 0.81 & 0.15 & 3.38 & 0.21 & 0.74 & 9.12 & 1.41 \\
\hline 27 & Rayagada & 0.38 & 2.40 & 0.73 & 0.11 & 1.82 & 0.17 & 0.61 & 8.39 & 1.88 \\
\hline 28 & Nabarangapur & 0.37 & 2.24 & 0.58 & 0.04 & 1.62 & 0.07 & 0.29 & 6.96 & 0.81 \\
\hline 29 & Koraput & 0.34 & 4.39 & 1.11 & 0.05 & 3.02 & 0.20 & 0.52 & 11.08 & 2.39 \\
\hline \multirow[t]{2}{*}{30} & Malkangiri & 0.52 & 2.02 & 0.69 & 0.06 & 1.62 & 0.10 & 0.40 & 5.59 & 0.83 \\
\hline & ODISHA & 0.93 & 3.69 & 1.31 & 0.38 & 4.12 & 0.62 & 2.22 & 13.24 & 4.10 \\
\hline
\end{tabular}

Source: Calculated from 2011 Census Data

Similarly if we take the breaking up of pattern of higher education we find that it is skewed in favour of non technical qualifications. Table 6 below explains the various components of higher education achieved by literate females and we find that a majority of them have pursued graduation other than technology. Almost all the districts show the same pattern. In medicine three districts are showing a percentage higher than the state average but that is due to the fact that the three medical colleges are established in these districts. Completing P.G other than technology is the second highest level of HE completed by the female literates. The nontraditional components such as dairying and veterinary sciences are hardly taken up by women.

Table 6: Percentage of Literate Women having Higher Education across different professions 
Status of Higher Education of Women in Odisha: An Inter District Analysis

\begin{tabular}{|c|c|c|c|c|c|c|c|c|c|}
\hline & & $\begin{array}{l}\text { Graduate } \\
\text { other } \\
\text { than } \\
\text { technical }\end{array}$ & $\begin{array}{l}\text { P.G } \\
\text { other } \\
\text { than } \\
\text { tech }\end{array}$ & $\begin{array}{l}\text { Engineering } \\
\text { and tech }\end{array}$ & medicine & $\begin{array}{l}\text { Agr and } \\
\text { dairying }\end{array}$ & Vet & Teaching & Others \\
\hline & ODISHA & 66.85 & 17.87 & 10.06 & 1.37 & 0.06 & 0.03 & 3.76 & 0.01 \\
\hline 1 & Bargarh & 71.72 & 15.93 & 7.10 & 1.31 & 0.09 & 0.02 & 3.82 & 0.00 \\
\hline 2 & Jharsuguda & 71.72 & 17.54 & 6.35 & 0.97 & 0.01 & 0.02 & 3.38 & 0.01 \\
\hline 3 & Sambalpur & 63.85 & 21.48 & 9.18 & 1.60 & 0.05 & 0.03 & 3.82 & 0.01 \\
\hline 4 & Sambalpur & 75.32 & 9.19 & 11.32 & 0.86 & 0.00 & 0.00 & 3.32 & 0.00 \\
\hline 5 & Sundargarh & 69.62 & 16.80 & 8.25 & 1.20 & 0.03 & 0.03 & 4.06 & 0.01 \\
\hline 6 & Kendujhar & 73.43 & 11.98 & 11.02 & 0.54 & 0.02 & 0.03 & 2.95 & 0.01 \\
\hline 7 & Mayurbhanj & 70.70 & 13.22 & 11.28 & 1.00 & 0.08 & 0.04 & 3.68 & 0.00 \\
\hline 8 & Baleshwar & 69.73 & 13.31 & 12.09 & 0.99 & 0.05 & 0.03 & 3.79 & 0.00 \\
\hline 9 & Bhadrak & 67.17 & 12.89 & 16.27 & 0.65 & 0.03 & 0.01 & 2.98 & 0.00 \\
\hline 10 & Kendrapara & 73.01 & 11.35 & 11.10 & 0.54 & 0.02 & 0.01 & 3.97 & 0.01 \\
\hline 11 & Jagatsinghapur & 71.43 & 14.06 & 9.69 & 0.68 & 0.02 & 0.02 & 4.09 & 0.00 \\
\hline 12 & Cuttack & 64.20 & 21.10 & 8.10 & 2.88 & 0.06 & 0.02 & 3.63 & 0.01 \\
\hline 13 & Jajapur & 72.84 & 12.97 & 10.29 & 0.67 & 0.04 & 0.01 & 3.19 & 0.00 \\
\hline 14 & Dhenkanal & 72.73 & 14.08 & 8.80 & 0.70 & 0.04 & 0.03 & 3.61 & 0.00 \\
\hline 15 & Anugul & 70.81 & 16.45 & 8.71 & 0.95 & 0.03 & 0.02 & 3.02 & 0.01 \\
\hline 16 & Nayagarh & 69.41 & 12.89 & 11.97 & 0.92 & 0.08 & 0.01 & 4.73 & 0.00 \\
\hline 17 & Khordha & 57.91 & 25.27 & 11.71 & 1.65 & 0.17 & 0.06 & 3.22 & 0.01 \\
\hline 18 & Puri & 69.39 & 16.80 & 9.36 & 0.80 & 0.03 & 0.01 & 3.60 & 0.00 \\
\hline 19 & Ganjam & 60.05 & 22.09 & 11.10 & 2.19 & 0.05 & 0.03 & 4.49 & 0.01 \\
\hline 20 & Gajapati & 62.34 & 18.09 & 9.42 & 1.21 & 0.00 & 0.03 & 8.90 & 0.00 \\
\hline 21 & Kandhamal & 70.05 & 16.21 & 6.09 & 1.06 & 0.07 & 0.07 & 6.45 & 0.00 \\
\hline 22 & Baudh & 71.16 & 12.06 & 9.60 & 0.68 & 0.05 & 0.05 & 6.40 & 0.00 \\
\hline 23 & Subarnapur & 75.70 & 12.64 & 5.79 & 0.96 & 0.03 & 0.00 & 4.88 & 0.00 \\
\hline 24 & Balangir & 73.16 & 14.59 & 6.34 & 1.23 & 0.02 & 0.02 & 4.60 & 0.03 \\
\hline 25 & Nuapada & 71.90 & 17.14 & 5.37 & 1.34 & 0.07 & 0.00 & 4.14 & 0.04 \\
\hline 26 & Kalahandi & 71.84 & 13.96 & 9.13 & 0.93 & 0.08 & 0.04 & 3.98 & 0.04 \\
\hline 27 & Rayagada & 66.78 & 17.48 & 10.01 & 0.90 & 0.02 & 0.02 & 4.78 & 0.02 \\
\hline 28 & Nabarangapur & 69.37 & 14.81 & 8.99 & 1.07 & 0.00 & 0.06 & 5.69 & 0.00 \\
\hline 29 & Koraput & 64.32 & 22.12 & 7.00 & 1.09 & 0.08 & 0.03 & 5.36 & 0.00 \\
\hline 30 & Malkangiri & 69.95 & 13.12 & 9.91 & 1.11 & 0.06 & 0.00 & 5.85 & 0.00 \\
\hline
\end{tabular}

Source: Compiled from 2011 census data

The above tables give an idea about the position of women as far as higher education is concerned. However, if one looks at the expenditure on education it is found to be very negligible and to think about expenditure on higher education for women as a subset of it cannot make much impact. For example, relation between budgeted expenditure on education and GSDP in 2012-13 shows that percentage of education budget of education department and other departments to GSDP is $3.42 \%$ as against the all India figure of $4.29 \%$. The percentage expenditure is highest for Mizoram(9.21\%).If one limits oneself to expenditure by education department only it is again much less. The figure is $3.02 \%$ for Odisha as against India figure of $3.45 \%$.

Table 7 below shows the expenditure on higher education as a percentage of GSDP and it shows that Odisha data is quite comparable to India. Expenditure on higher education as a percentage of GSDP is much less than expenditure on total education as a percentage of GSDP. Thus expenditure on higher education vis a vis rest of the total education as a percentage of GSDP reflects that much has to be done in this area. 
Table 7: Relation between budgeted Expenditure on Education and GSDP 1980-81 to 2009-10

\begin{tabular}{|l|c|c|c|c|c|c|c|c|}
\hline & \multicolumn{3}{|c|}{ Expenditure on Higher Education as \% to } & \multicolumn{4}{c|}{ Expenditure on Total Education as \% to } \\
GSDP
\end{tabular}

The Odisha government presented Rs. 84,487.77-crore budget for 2015-16 that focused on infrastructure, education and agriculture. School and Mass Education Department received the highest allocation of Rs. 9979.49 crore as against Rs. 9327.12 crore provided in 2014-15. Similarly, for 2016-17, Rs.94, 052.65 crore budget with focus on agriculture and social sectors was presented. The total outlay for general education is pegged at Rs.13, 396.35 crore, or 13.61 percent of the total.

\section{IV}

\section{SUMMARY CONCLUSIONS AND POLICY PRESCRIPTIONS}

Investment in womens education is an investment in future. What can be concluded from above analysis? It finds that a very low percent of literate females go for higher education. Among the women opting for higher education, again a high percentage of them go for graduation without technology. There is huge inter district disparities across social groups in HE.

Odisha's higher education sector- just like India's- is still plagued with several challenges like inequitable access to higher education by community, gender and geography and inadequacy of high-quality research and educational institutions, resulting in sub-optimal outcomes. The representation of weaker sections of the society including women still remains low as measured against their share in the total population even after enforcement of reservation of seats in all higher educational institutions. Non-availability of adequate higher education facilities in rural areas also prevents talented girls from opting for it. In very poor families, the girls start earning from very childhood, and sending them to distant places for education amounts to loss of source of income for the parents. Social factors are even more outweighing in creating hurdles for higher education for women. For social and cultural reasons, the girl often doesn't receive same medical, emotional and educational attention as her male counterpart. The girl child is seen as a burden, a bearer of exorbitant dowry. Though there is a change in the attitude of upper and middle income group in cities, and higher education for girls is taken for granted, it is not with a career motive but rather as preparation for meeting the ultimate goals of her life like matrimony and motherhood. The objective of higher education to ensure women's autonomy in decision-making, freedom of expression and control over resources is hardly achieved because of social hurdles. More incentives like scholarships, free ships have to be provided to deserving girls so that the education expenses don't act as an obstacle. The present system more or less caters to the requirements of urban elite to the disadvantage of about 72 per cent of the people living in rural areas. There is an urgent need to introduce policy interventions to reverse the trend and reshape the system so as to make it poor-friendly and ruraloriented. No doubt, substantial expansion of higher educational facilities for women has been achieved in the process. Women enrolment in higher education which was less than 10 per cent of the total on the eve of Independence went up to 44 per cent during 2010-11.

One measure of accountability is the amount of money spent on women's programmes. It is important as ensuring equality cannot be achieved unless there are committed funds available for implementing the various policies and schemes introduced by the government. Recent data indicates that though expenditure for social services has been increasing but Women Specific programmes constitute less than $1 \%$ of it. Almost all the women specific programmes are concentrated in the Department of Women \& Child Development but it has to be noted that the women component planning mandates that all sectors should have $30 \%$ of its resources to be allocated for women. There is a need for inclusion of the very poor and marginalized. Under these situations education and political power will assist to climb barriers. Women are moving forward in every field motivated by the urge to excel and to find their own space in this universe. Keeping the long run effect in mind, we should be consciously planning about higher education for women.

\section{REFEFERENCE}

[1] Economic Times, 13th January, 2004.

DOI: 10.9790/0837-2108070110 www.iosrjournals.org $\quad 9 \mid$ Page


[2] Government of India, 2011 Census Data, $D D W-2100 C-2011$ assessed from Internet.

[3] Government of Orissa, White Paper on Orissa State Finances, March $29^{\text {th }}, 2004$,

[4] Government of Odisha, Finance Department Reports for various years.

[5] Hans Asha\& Dr. Amrita Patel, "Women of Odisha: Status and Challenges", Odisha Review; FebruaryMarch - 2012, pp40-47.

[6] Report of Directorate of Elementary Education, 1980-89.

[7] Samal, K.C. "Developing Human Capital in Orissa: Role of Education, Orissa Economic Journal, Vol. XXXVIII No1\&2, Jan-June \& July-Dec.2006.

[8] Satapathy Sadhana, "Some Aspects Of Expenditure On Higher Education In Orissa", Orissa Economic Journal, vol-39, No.1\&2, pp.203-213,2007.

[9] Tilak, J.B.G. (2004): "Public Subsidies in Education in India", Economic and Political Weekly, Vol xxxix No.4, January24-30.

[10] UNICEF Report, 1992. 